\author{
G. A. Malfa, R. Acquaviva, A. A. E. Bucchini, S. Ragusa, F. M. Raimondo \\ \& V. Spadaro
}

\title{
The Sicilian wild cabbages as biological resources: taxonomic update and a review on chemical constituents and biological activities
}

\begin{abstract}
Malfa, G. A., Acquaviva, R., Bucchini, A. A. E., Ragusa, S., Raimondo, F. M. \& Spadaro, V.: The Sicilian wild cabbages as biological resources: taxonomic update and a review on chemical constituents and biological activities. - Fl. Medit. 30: 245-260. 2020. — ISSN: 1120-4052 printed, 2240-4538 online.

Considering the growing interest that wild brassicas have as sources of bioactive molecules as well as a genetic resource, the authors review and update the taxonomy of Brassica sect. Brassica, limited to the native flora of Sicily, an island considered to be an active diversification center for the group of species of the aforementioned section. Regarding the taxonomic aspects, Brassica tardarae is here considered a subspecies of $B$. rupestris; the distinction at the subspecific level of $B$. raimondoi, a critical taxon included in $B$. incana, is also confirmed. In addition, two new subspecies are proposed, respectively in $B$. incana and B. rupestris. The taxonomic information relating to the taxa reported is enriched by synthetic chorological data. A thorough examination of the literature concerning the chemical aspects and biological activity of some Sicilian taxa referred to Brassica sect. Brassica, allowed to highlight not only important bioactive molecules such as glucosinolates, but also the demonstrated biological activities. From these studies, therefore, the enormous potential of Sicilian wild cabbages emerges, not only as a recognized genetic resource, but also as a biological and nutraceutical one. This would demonstrate the considerable economic importance of these plants which can have positive effects on the innovation of agricultural production.
\end{abstract}

Key words: vascular flora, Brassica sect. Brassica, Brassicaceae, taxonomy, phytochemicals, glucosinolates. Sicily.

\section{Introduction}

The Mediterranean region due to its mild but variable clime and the fertility of its soils has been the cradle of a complex of botanical species of agricultural and food significance. In particular Sicily, due to its geographical isolation, represents a centre of biodiversity for many wild Brassica species that importantly contributed by the crossbreeding, to the diversity of Sicilian crops, so providing some varietal groups determinate by unique characteristics and marked organoleptic qualities (Branca \& al. 2018). Moreover, some wild 
Brassica species have been an important source of food in the diet of Sicilian populations for centuries as a part of the Mediterranean diet and several studies have been documented the nutritional and the medicinal properties of the edible wild plants respect to the cultivated crops (Licata \& al. 2016; Berni \& al. 2018). These searches have attributed the beneficial effects on human health of Brassicaceae species and of the horticultural varieties to the presence of glucosinolates and phytochemical compounds such as polyphenols, carotenoids, vitamins and trace minerals (Baecher 1994; Kataya \& Hamza 2008).

Interestingly, the particular profiles and the high concentrations of wild Brassica secondary metabolites vary enormously between species and genetic and epigenetic factors largely influence their production. The protective activities resulted to be linked to the ability of glucosinolates to modulate many enzymes involved in carcinogens metabolism and to increase the cellular antioxidant capacity (Prieto \& al. 2019). From a taxonomy point of view, the $B$. oleracea group forms a distinct unit known as $B$. oleracea cytodeme, characterized by the same diploid genome $2 n=18(x=9)$ (Snogerup \& al. 1990). It includes a total of 13 taxa at specific and intraspecific level, among them 10 are endemism exclusively present in some restricted areas of Sicily. Suffruticose perennials and not obligate chasmophytes plants, thrive on rocky soils from the coast to up to an altitude of $1400 \mathrm{~m}$. Young plants are herbaceous, but in the adults the main stem turns woody, old individuals usually show a shrubby shape (Raimondo \& al. 1991). The classification of these taxa at specific and intraspecific level resulted complex and sometimes controversial due to some peculiar characteristics such as the susceptibility to mutations and the crossbreeding among species.

Many studies based on morphological observations, molecular and biological analysis tried to provide certain indication about the relationship within the populations belonging this group. The most reliable results obtained using random amplified polymorphic DNA markers, have shown that the Sicilian taxa are genetically distinct from $B$. oleracea $\mathrm{L}$. and have indicated that $B$. incana Ten., B. macrocarpa Guss. and the B. villosa-rupestris group represent distinct clades with high variability among the species and among the various isolated populations (Geraci \& al. 2001). In this context, the present contribution reviews all the studies on wild Sicilian taxa of Brassica sect. Brassica (Brassicaceae) including new taxa recently described or proposed here as new, and for the first time in our knowledge, we report a detailed summary on the phytochemical composition and the biological activities of the few species and subspecies analysed.

\section{Metodology and contents}

In the present article we based our investigation on different databases including Web of Science, PubMed, Google scholar, Scopus. To achieve better results, we used the combinations of some key words: Brassica, Brassicaceae, Taxonomy, Chorology, Ecology, IUCN, genetic, phytochemicals, secondary metabolites, bioactive compounds, nutraceuticals, biological activities, cancer, disease, Brassica incana subsp. incana, Brassica incana subsp. raimondoi Brullo \& al., Brassica insularis Moris, Brassica macrocarpa, etc.

Original studies concern:

- the reduction to subspecific level of the recently described Brassica tardarae Ilardi, Troì

\& Geraci (2020); 
- the re-proposal at the subspecific level of B. raimondoi Sciandrello \& al. (B. incana subsp. raimondoi (Sciandrello \& al.) Raimondo \& Spadaro);

- the proposition of two new subspecific taxa in the context of B. incana and B. rupestris Raf. respectively.

\section{Taxonomy}

Brassica in the native flora of Sicily is represented by numerous specific and infraspecific taxa. In particular, the sect. Brassica that comprises polyennial suffruticose species, relatives of cultivated cabbages. Within the whole group, the variability of the populations is quite accentuated and the fact of being often confined both spatially and ecologically, has made it possible to distinguish various subspecie in $B$. incana, $B$. rupestris and $B$. villosa, especially in more wide distribution and variability.

The recent checklist of the Italian flora (Bartolucci \& al. 2018) assigns the following native taxa to Sicily:

Brassica incana Ten. subsp. incana

Brassica insularis Moris

Brassica macrocarpa Guss.

Brassica rupestris Raf. subsp. rupestris

Brassica rupestris subsp. hispida Raimondo \& Mazzola

Brassica trichocarpa C. Brullo, Brullo, Giusso \& Ilardi

Brassica villosa Biv. subsp. villosa

Brassica villosa subsp. bivonana (Mazzola \& Raimondo) Raimondo \& Mazzola

Brassica villosa subsp. brevisiliqua (Raimondo \& Mazzola) Raimondo \& Geraci

Brassica villosa subsp. drepanensis (Caruel) Raimondo \& Mazzola

Brassica villosa subsp. tineoi (Lojac.) Raimondo \& Mazzola

Recent studies have led to the description of a new species, Brassica tardarae Ilardi Troì \& Geraci (2020) which is added to the others listed. Deeming the approach of Snogerup \& al. (1990), which in Sicily recognizes on a specific level only B. macrocarpa, $B$. insularis, $B$. rupestris and $B$. villosa, and considering $B$. trichocarpa to be distinct at a specific level, a new taxonomic framework for Brassica sect. Brassica in Sicily. This is also based on new collections and field observations by two of the authors (F. M. Raimondo and V. Spadaro) and, again, following the recent description by B. tardarae.

\section{Critical analysis}

Brassica incana subsp. hirta Raimondo \& Spadaro subsp. nov.

Differs from $B$. incana Ten. subsp. incana for its very hairy indument, for the leaves usually bare o lobed at the base, flowers always yellow (Fig. 1).

Type: Sicilia, Madonie in Contrada Gonato (Castelbuono), sulle rupi calcaree, ca. 1100 m. s.l.m. Raimondo (PAL, holotype; PAL-Gr and FI, isotype). 


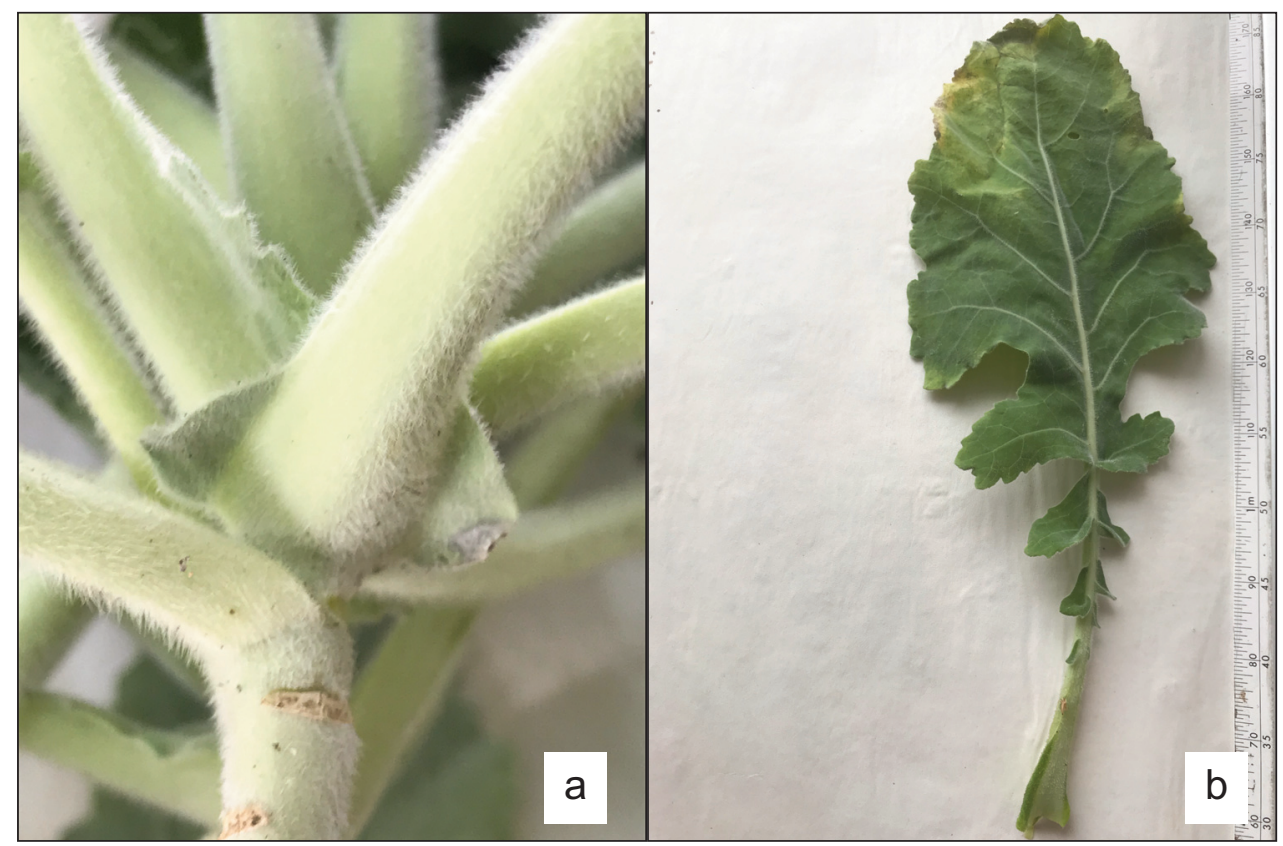

Fig. 1. Details of Brassica incana subsp. hirta: a) accentuated hairiness of the stem and petiole; b) leaf lobed at the base.

B. incana subsp. raimondoi (Sciandr., C. Brullo, Brullo, Giusso, Miniss. \& Salmeri) Raimondo \& Spadaro [Bas. Brassica raimondoi Sciandr., C. Brullo, Brullo, Giusso, Miniss. \& Salmeri, Pl. Biosyst. 147(3): 813 (2013).

This taxon, described at a specific level as B. raimondoi, is represented by an isolated, small population located on the calcareous sub-coast of Castelmola, overlooking the well-known tourist center of Taormina (Messina), and is readily distinguished by the white color of the flowers. It is in contact with the coastal population of $B$. incana subsp. incana with yellow flowers from Capo S. Alessio. From this, B. raimondoi is distinguished by various characters as well as by the color of the flowers, the latter character almost evenly distributed in the population. However, the same also occurs in the Tyrrhenian coastal population as is appreciated in that of Capo d'Orlando, where plants with yellow and white flowers coexist in the same site. On the Ionian side of Sicily, the isolation of the two populations - coastal (Capo S. Alessio) and sub-coastal (Castelmola) respectively - is not only spatial but also phenological, so that they are hardly able to contract reproductive relationships, remaining genetically isolated. Due to the set of discriminating characters of the taxon described by Sciandrello \& al. (2013), this taxon, according to our interpretation, already expressed (Raimondo \& Spadaro 2015), can retain its autonomy in the subspecific rank; this is also based on the systematic approach followed in our studies on Sicilian wild brassicas (Raimondo \& al. 1991; Raimondo \& Mazzola 1997). 
Brassica rupestris subsp. monilicarpa Raimondo \& Spadaro subsp. nov.

Differs from B. rupestris Raf. subsp. rupestris for the smaller, crassulent and glabrous leaves; adaxial surface of the blade endowed with few or many short bulbous hairs; shorter siliqua, often moniliform, longer beak, generally with 1-3 seeds, exceptionally up to 6 (Fig. 2).

Type: Palermo, pendici settentrionali di Monte Gallo, su litosuolo calcareo, $150 \mathrm{~m}$ a.s.1., 25.V.2015, Raimondo \& Spadaro (PAL, holotype; PAL-Gr and FI isotype).

Brassica rupetris subsp. tardarae (Ilardi, Trò̀ \& Geraci) Raimondo, comb. et stat. nov. [Bas. Brassica tardarae Ilardi, Troìa \& Geraci in Plants 9, 947: 4/10 (2020).

Type: Gole della Tardara, territorio di Sambuca di Sicilia (provincia di Agrigento), in rupibus calcareis, Ilardi, Troìa, Geraci, 9 May 2019 (Holotypus PAL 109799).

Similar to Brassica rupestris Raf., differs mainly for the form of blade and fruit, shortest and distinctly tetragonous. Described on a specific level as $B$. tardarae, the taxon, is to be considered within the variability of B. rupestris. Some leaf characters support this different interpretation: such as the presence in the dorsal face of the blade of bulbose, hispid hairs especially, that is typical in B. rupestris and in its other subspecies. Considering the distribution of the population, separated from the others referring to $B$. rupestris, we propose here to assign this taxon to the rank of subspecies.

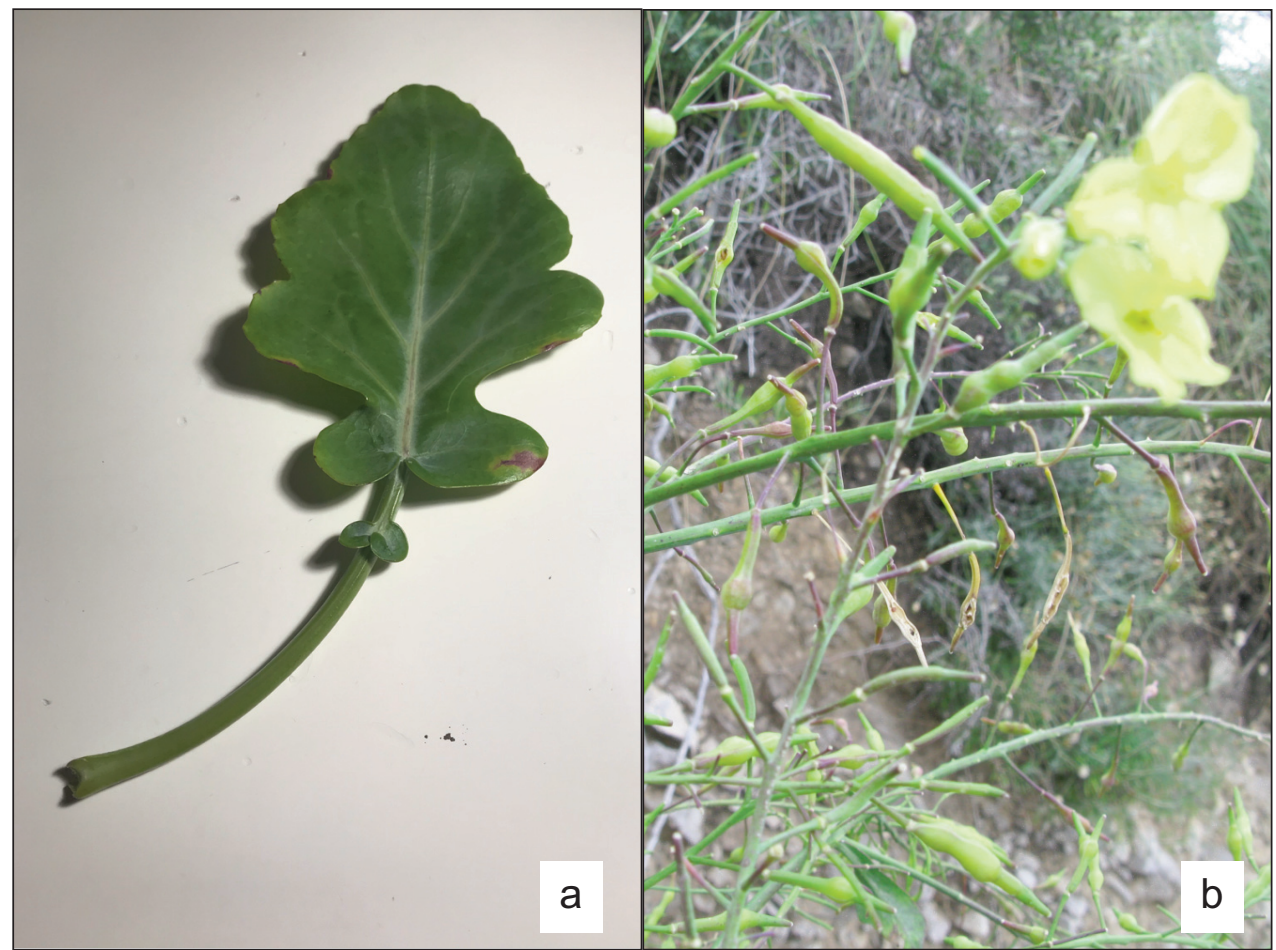

Fig. 2. Details of Brassica rupestris subsp. monilicarpa: a) crassulent leaf; b) fruits. 


\section{Updated taxonomic framework}

Based on the above, the resulting taxonomic framework is therefore the following:

Brassica incana Ten. subsp. incana

Distribution: Sicily, eastern Tyrrhenian and Ionian coasts of the island.

Brassica incana subsp. hirta Raimondo \& Spadaro subsp. nov.

Distribution: Sicily, Madonie Mountains (Castelbuono, Palermo).

B. incana subsp. raimondoi (Sciandr., C. Brullo, Brullo, Giusso, Miniss. \& Salmeri) Raimondo \& Spadaro

Distribution:Sicily, Ionian coast to Castelmola (Messina)

Brassica insularis Moris

Distribution: Sicily, Pantelleria island.

Brassica macrocarpa Guss.

Distribution: Sicily, Egadi islands (Favignana and Marettimo).

Brassica rupestris Raf. subsp. rupestris

Distribution: Sicily, limestone reilefs of the Tyrrhenian coast between Cefalù and Monte Pellegrino and in the inside until Rocca Busambra (Corleone, Palermo). Critical the presence of the species in S. Italy.

Brassica rupestris subsp. monilicarpa Raimondo \& Spadaro subsp. nov.

Distribution: Sicily, Monte Gallo and Monte Billiemi (Palermo).

Brassica rupestris subsp. hispida Raimondo \& Mazzola

Distribution: Sicily, Monte Pizzuta (Piana degli Albanesi, Palermo).

Brassica rupetris subsp. tardarae (Ilardi, Trò̀ \& Geraci) Raimondo, comb. et stat. nov. Distribution: Sicily, Tardara, gorges between Menfi and Sambuca di Sicilia (Agrigento).

Brassica trichocarpa C. Brullo, Brullo, Giusso \& Ilardi, Phytotaxa 122(1): 47 (2013).

Distribution: Sicily, Monte Cuccio (Palermo).

Brassica villosa Biv. subsp. villosa

Distribution: Sicily, Monte Occhio (Partinico, Palermo).

Brassica villosa subsp. bivonana (Mazzola \& Raimondo) Raimondo \& Mazzola

Distribution: N.W. Sicily, to Monte Inici until Monte Passo del Lupo and Monte Cofano (Trapani). 
Brassica villosa subsp. brevisiliqua (Raimondo \& Mazzola) Raimondo \& Geraci Distribution: Sicily, Tyrrhenian coast between San Vito Lo Capo and Monte Cofano (Trapani).

Brassica villosa subsp. drepanensis (Caruel) Raimondo \& Mazzola Distribution: Sicily, Monte San Giuliano (Erice, Trapani).

Brassica villosa subsp. tineoi (Lojac.) Raimondo \& Mazzola Distribution: C. Sicily (Terrapilata presso Caltanissetta, Marianopoli, S. Caterina, Serre di Chibbò, Vallelunga, Campobello di Licata, Rocca Limata-Petralia Sottana).

\section{Phytochemical characteristics}

In recent decades, epidemiological evidence suggests that consuming plant-based foods containing significant amounts of bioactive molecules, also known as phytochemicals, provides a large number of human health benefits (Baecher 1994; Kataya \& Hamza 2008). The data of the scientific literature in particular report that vegetables belonging to the Brassicaceae family, in addition to their not negligible nutritional values, are a good source of secondary metabolites with different biological activities such as vitamins, carotenoids, phenolic compounds, terpenes and glucosinolates, a class of biologically active compounds characteristic of this family (Prieto \& al. 2019).

Moreover, many studies based on phytochemical and genetic analysis, focus attention on the potential higher levels of bio-actives in ancient varieties and wild species than the commercial cultivars belonging the Brassica oleracea complex $(n=9)$ (Giamoustaris \& Mithen 1996; Branca \& al. 2018). Plant secondary metabolites are mostly involved in plant defence mechanisms against biotic and abiotic stress, wild species which grow well in a wild context, possess some more efficient stress response mechanisms than those of cultivated varieties (Berni \& al. 2018).

The more capable defence mechanisms may be correlated with a larger quantity of phytochemicals (Berni \& al. 2018).Few researches refer to the phytochemical composition of wild Sicilian taxa within the present review (Table 1). The first study found based on the research methods of this work, was conducted by Mithen and collaborators on the levels and distribution of glucosinolates in different wild populations of the $B$. oleracea group including B. incana, B. rupestris, B. drepanensis, B. macrocarpa, B. insularis. Wild brassicas showed higher total glucosinolate content than cultivated forms with a variable glucosinolate pattern (Mithen \& al. 1987). Particularly, Sicilian species showed the following amounts for B. incana $11.27 \mu \mathrm{mol} / \mathrm{g}$, B. rupestris $11.88 \mu \mathrm{mol} / \mathrm{g}$, B. drepanensis 4.73 $\mu \mathrm{mol} / \mathrm{g}$, B. macrocarpa $3.76 \mu \mathrm{mol} / \mathrm{g}$, B. insularis $12.26 \mu \mathrm{mol} / \mathrm{g}$, characterized by the predominant presence of glucoiberin and glucoiberverin as main compounds in $B$. rupestris and $B$. drepanensis respectively. Glucoiberin was found at high level only in B. rupestris among the examined taxa (Mithen \& al. 1987). A successive study confirmed high levels of 3-methylthiopropyl glucosinolate and a smaller amount of 3-methylsulphinylpropyl glucosinolate in $B$. drepanensis and high levels of 2-propenyl glucosinolate in $B$. atlantica $(B$. insularis) (Giamoustaris \& al. 1997). 
In a study with the purpose to selective increase 4-methylsulphinylbutyl glucosinolate as promising chemopreventive agent in broccoli by hybridization with wild species, the authors reported that B. villosa $(124 \pm 19 \mu \mathrm{mol} / \mathrm{g})$, B. drepanensis $(62.6 \pm 10.9 \mu \mathrm{mol} / \mathrm{g})$ and $B$. atlantica (B. insularis, $95.3 \pm 26.6 \mu \mathrm{mol} / \mathrm{g}$ ) demonstrated 10 -fold greater level of total glucosinolates than the cultivars $(4.3-16.6 \mu \mathrm{mol} / \mathrm{g})$, with the predominantly presence of 3-methylsulphinylpropyl $(119 \pm 18 \mu \mathrm{mol} / \mathrm{g}), 3$-methylthiopropyl $(51.6 \pm 9.3 \mu \mathrm{mol} / \mathrm{g})$ and 2-propenyl $(92.8 \pm 25.4 \mu \mathrm{mol} / \mathrm{g})$ glucosinolates, respectively. Resulted hybrids showed similar total levels of aliphatic glucosinolates to those found in the wild species (Faulkner \& al. 1998).

Another comparative research on glucosinolates profile reveleated that B. macrocarpa possess a peculiar content of sinigrin whereas $B$. rupestris displayed a similar profile to those of the examined crops (Branca \& al. 2002).

The most inclusive study regarding the reviewed species and subspecies is by Scialabba $\&$ al. (2019) in which is reported the tocopherol, fatty acid and phytosterol content in dry seeds of nine wild taxa of Sicilian Brassica sect. Brassica precisely, B. villosa subsp. villosa; $B$. villosa subsp. bivonana; $B$. villosa subsp. drepanensis; $B$. villosa subsp. tineoi; $B$. villosa subsp. brevisiliqua; B. rupestris subsp. rupestris; B. rupestris subsp. hispida; $B$. macrocarpa; $B$. incana. The research shows that $\alpha$ - and $\gamma$-tocopherol were the major isomers detected and total tocopherol content reported vary from the lower content of 125.1 $\pm 13.6 \mathrm{mg} / \mathrm{kg}$ of $B$. macrocarpa to the higher of $597.8 \pm 54.1 \mathrm{mg} / \mathrm{kg}$ and $541.3 \pm 30.6$ $\mathrm{mg} / \mathrm{kg}$ for $B$. villosa subsp. villosa and B. villosa subsp. drepanensis respectively. The seeds fatty acids composition of the taxa analysed showed a similar profile with the unsaturated fractions $(52.5-66.5 \%)$ more abundant than saturated ones $(33.5-47.5 \%)$. B. incana showed the highest total fatty acids content $(2761.5 \pm 123.1 \mathrm{mg} / \mathrm{kg})$ and the higher percentage of unsaturated fatty acids $(66.5 \%)$. Total phytosterols amount were detected significantly higher in four of the five subspecies of $B$. villosa group (B. villosa subsp. villosa $(495.7 \pm 24.0 \mathrm{mg} / \mathrm{kg})$, B. villosa subsp. bivonana $(565.4 \pm 19.1 \mathrm{mg} / \mathrm{kg})$, B. villosa subsp. drepanensis $(456.8 \pm 19.3 \mathrm{mg} / \mathrm{kg})$, B. villosa subsp. tineoi $(518.0 \pm 15.6 \mathrm{mg} / \mathrm{kg})$ and in all the examined taxa relatively to the total phytosterols content, sytosterol was the most abundant with $61.7-69.6 \%$, followed by brassica sterol with $16.0-19.8 \%$ and campesterol with 11.9-20.7\%. The authors concluded indicating that these taxa, belonging $B$. villosa group are potentially the most bioactive ones due to the highest total tocopherol, $\gamma$-tocopherol and phytosterol contents (Scialabba \& al. 2010).

The analysis of volatile constituents in leaves and roots of B. incana in a work of Tripodi \& al. (2012) revealed a large number of volatile constituents such as alcohols, aldehydes, esters, acids, ketones and terpenes including thiocyanates and isothiocyanates. For the latter class belonging to glucosinolates derivatives, the roots showed the highest content and the largest number this compounds (leaves $2877 \mu \mathrm{g} / \mathrm{g}$, roots $76824 \mu \mathrm{g} / \mathrm{g}$ ). Methyl thiocyanate $(2262 \mu \mathrm{g} / \mathrm{g})$, 3-butenyl isothiocyanate $(2262 \mu \mathrm{g} / \mathrm{g})$, 4-pentenyl isothiocyanate $(2039 \mu \mathrm{g} / \mathrm{g}), 3-$ methylthiopropyl isothiocyanate $(\mu \mathrm{g} / \mathrm{g} 360)$ and Hexyl isothiocyanate (181 $\mu \mathrm{g} / \mathrm{g})$ were listed in roots and only 3-butenyl isothiocyanate $(28770 \mu \mathrm{g} / \mathrm{g})$ was found in $B$. incana leaves (Tripodi \& al. 2012).

Seeds of wild population of $B$. incana, B. rupestris, B. villosa and B. macrocarpa were also analysed for their glucosinolate profile, ascorbic acid, polyphenols and carotenoid content by Branca \& al. (2013) revelating that the level of total glucosinolates varied over 
a wide range. The highest content of glucosinolates was found in a population of $B$. rupestris $(78.5 \pm 8.5 \mu \mathrm{M} \mathrm{dw})$ with a remarkable presence of glucoiberin and sinigrin and the absence of glucoraphanin. B. villosa, B. incana and B. macrocarpa showed a glucosinolates content of $37.8 \pm 2.4,51.7 \pm 8.2$ and $53.0 \pm 2.7 \mu \mathrm{M}$ dw respectively with the main compounds identified as glucoiberine, progoitrine, glucoraphanin, sinigrin, sinalbin, gluconapin, glucoiberverin, glucobrassicin, gluconasturtiin, neo-glucobrassicin. Gluconapin and glucobrassicin were ubiquitous in all the analysed taxa. B. rupestris displayed the highest amount of ascorbic and also the greater content of total carotenoids while the population of $B$. incana exhibited the highest content of total polyphenols (Branca \& al. 2013).

In a research with the aim to evaluate if soil properties may affect the accumulation of secondary metabolites in B. rupestris, the authors reported the highest poliphenols content in B. rupestris grown in poor soil ( $4342 \mu \mathrm{g} / \mathrm{g}$ as tannic acid) conversely, the glucosinolates were almost higher in B. rupestris grown in the more fertile soil with a major content of organic matter (2442 $\mu \mathrm{M} / \mathrm{g})$ (Muscolo \& al. 2019).

The phenolic compositions of $B$. incana leaves and inflorescences recently reported by Miceli \& al. (2020), identified a total of 17 and 20 polyphenolic compounds and a total phenolic content of $37.20 \pm 0.93 \mathrm{mg}$ gallic acid equivalent/g extract and $27.98 \pm 0.32 \mathrm{mg}$ gallic acid equivalent/g extract respectively. Both extracts contain derivatives of the flavonols quercetin, kaempferol, and isorhamnetin, and of the hydroxycinnamic acids sinapic acid and ferulic acid, coniugated with sugars or hydroxycinnamic acids. Qualitatively, the polyphenolic profiles of the extracts differ only for the compounds kaempferol-3-O-diglucoside-7-O-glucoside, quercetin-3-sophoroside-7-glucoside, and feruloylmalate, isolated only in the inflorescences. The most abundant flavonoids for leaves extract were isorhamnetin-3-glucoside-7-glucoside $(3.33 \mathrm{mg} / \mathrm{g} \pm 0.54 \%$ relative standard deviation (RSD)), kaempferol-3-sinapoylsophoroside-7-glucoside $(2.84 \mathrm{mg} / \mathrm{g} \pm$ $0.77 \% \mathrm{RSD})$ and kaempferol-3-feruloylsophoroside-7-glucoside $(2.11 \mathrm{mg} / \mathrm{g} \pm 0.98 \%$ RSD); for the inflorescences extract kaempferol-3-feruloylsophoroside-7-glucoside (2.14 $\mathrm{mg} / \mathrm{g} \pm 0.48 \% \mathrm{RSD})$ isorhamnetin-3-glucoside-7-glucoside (1.79 mg/g $\pm 0.32 \% \mathrm{RSD})$ and quercetin-3-hydroxyferuloylsophoroside-7-glucoside (1.59 mg/g $\pm 0.57 \%$ RSD) were the main compounds (Miceli \& al. 2020).

Lastly chronologically, a phytochemical characterization of four different Sicilian species specifically, B. incana, B. macrocarpa, B. villosa, and B. rupestris was conducted by Picchi $\&$ al. (2020). The study reported that the content of the main phenolics ranged from 163.9 (B. macrocarpa) to 533.9 (B. incana) $\mathrm{mg} / 100 \mathrm{~g}$ dry weight (d.w.), ascorbic acid from 7.6 (B. villosa) to 375.8 (B. villosa) $\mathrm{mg} / 100 \mathrm{~g}$ d.w., and of total biothiols from 0.59 (B. macrocarpa) to 5.13 (B. villosa) $\mathrm{mg} / 100 \mathrm{~g} \mathrm{~d}$.w. Interestingly the authors noted that wild Brassica species studied showed a higher content of flavonol derivatives with respect to $B$. olearea crops, where gentiobiosides are the most representative phenolic compounds. The most abundant compounds isolated in the different wild species were: kaempferol synapoyl glucoside (67.5-81.3 mg/100 g d.w.), kaempferol cafeoyl glucoside (43.5-62.5 $\mathrm{mg} / 100 \mathrm{~g}$ d.w.), and kaempferol feruloyl glucoside $4(52.3-99.7 \mathrm{mg} / 100 \mathrm{~g} \mathrm{d.w.})$ in the samples of $B$. incana; Kaempferol feruloyl glucoside $(30.7 \pm 1.8 \mathrm{mg} / 100 \mathrm{~g}$ d.w.) kaempferol glucosides $(23.7 \pm 6.6$ and $28.1 \pm 1.9 \mathrm{mg} / 100 \mathrm{~g}$ d.w., in B. macrocarpa; quercetin sinapoyl glucoside (12.5-73.7 mg/100 g d.w.), kaempferol feruloyl glucoside (45.4-74.8 $\mathrm{mg} / 100 \mathrm{~g}$ d.w.), and kaempferol synapoyl glucoside (19.5-62.0 mg/100 g d.w.) in $B$. 
Table 1. Bioactive phytochemical components of some wild Sicilian taxa of Brassica sect. Brassica.

\begin{tabular}{|c|c|c|c|}
\hline Taxa & Plant Organ & Phytochemicals & References \\
\hline \multicolumn{4}{|l|}{ B. incana } \\
\hline B. rupestris & \multirow{4}{*}{ Leaf } & \multirow{3}{*}{ Glucosinolates } & \multirow{4}{*}{$\begin{array}{l}\text { Mithen \& al. } \\
\quad 1987\end{array}$} \\
\hline B. drepanensis & & & \\
\hline B. macrocarpa & & & \\
\hline B. insularis & & & \\
\hline $\begin{array}{l}\text { B. drepanensis } \\
\text { B. insularis (B. atlantica) }\end{array}$ & Leaf & Glucosinolates & $\begin{array}{c}\text { Giamoustaris A. \& Mithen R } \\
1996\end{array}$ \\
\hline $\begin{array}{l}\text { B. drepanensis } \\
\text { B. villosa } \\
\text { B. insularis (B. atlantica) }\end{array}$ & Inflorescence & Glucosinolates & $\begin{array}{c}\text { Faulkner \& al. } \\
1998\end{array}$ \\
\hline $\begin{array}{l}\text { B. macrocarpa } \\
\text { B. rupestris }\end{array}$ & Leaf & Glucosinolates & $\begin{array}{l}\text { Branca \& al. } \\
\quad 2002\end{array}$ \\
\hline \multicolumn{4}{|l|}{ B. villosa } \\
\hline \multirow{2}{*}{\multicolumn{4}{|c|}{$\begin{array}{l}\text { B. bivonana } \\
\text { B. drepanensis }\end{array}$}} \\
\hline & & & \\
\hline \multicolumn{4}{|l|}{ B. tinei } \\
\hline B. brevisiliqua & Seed & Fatty Acids, Phytosterols & 2010 \\
\hline \multicolumn{4}{|l|}{ B. hispida } \\
\hline \multicolumn{4}{|l|}{ B. macrocarpa } \\
\hline \multicolumn{4}{|l|}{ B. incana } \\
\hline B. incana & Leaf and root & $\begin{array}{l}\text { Alcohols, Aldehydes, Esters, } \\
\text { Acids, Ketones, Terpenes } \\
\text { Thiocyanates, Isothiocyanates }\end{array}$ & $\begin{array}{l}\text { Tripodi \& al. } \\
\quad 2012\end{array}$ \\
\hline B. incana & & Ascorbic Acid, Polyphenols, & Branca \& al. \\
\hline B. rupestris & Leaf & & 2013 \\
\hline \multicolumn{4}{|l|}{ B. villosa } \\
\hline \multicolumn{4}{|l|}{ B. macrocarpa } \\
\hline B. rupestris & Leaf & $\begin{array}{c}\text { Total Phenols, Glucosinolates, } \\
\text { Anthocyanins, Flavonoids, } \\
\text { Ascorbic Acid }\end{array}$ & $\begin{array}{l}\text { Muscolo \& al. } \\
2019\end{array}$ \\
\hline B. incana & Leaf and Inflorescence & Total Phenols, Polyphenols & $\begin{array}{l}\text { Miceli \& al. } \\
\quad 2020\end{array}$ \\
\hline \multicolumn{4}{|l|}{ B. incana } \\
\hline B. macrocarpa & & Phenolics, Ascorbic Acid, & Picchi \& al. \\
\hline B. villosa & Leaf & Biothiols & 2020 \\
\hline B. rupestris & & & \\
\hline
\end{tabular}


rupestris extracts; kjaempferol synapoyl glucosides (24.8-86.1 mg/100 g d.w., 25.8-81.4 $\mathrm{mg} / 100 \mathrm{~g}$ d.w.), quercetin sinapoyl glucoside (11.6-76.1 mg/100 g d.w.), kaempferol-3-Odiglucoside-7-O-diglucoside (46.9-80.4 mg/100 g d.w.), in B. villosa extracts. A higher amount of hydroxycinnamoyl gentiobiosides particularly the compound 1,2-disinapoyl gentiobioside, was found in B. incana and B. villosa compared to B. rupestris and $B$. macrocarpa (Picchi \& al. 2020).

\section{Biological activities}

Several species of Brassica sect. Brassica show nutritional, pharmaceutical and industrial importance. Epidemiological studies have shown a correlation between the consumption of broccoli (B. oleracea) and the risk of developing diverse human diseases (Baecher 1994; Kataya \& Hamza 2008). These health benefits are to their secondary metabolites such as nitrogen-sulfur derivatives (glucosinolates, isothiocyanates), polyphenols including idrossicinnamic acids and flavonoids, trace minerals such as selenium and several vitamins which possess antioxidant, antimicrobial, anti-inflammatory, anti-obesity, antidiabetic, anticancer and immunomodulatory properties (Gan \& al. 2017; Le \& al. 2020). In vitro, in vivo studies and clinical trials have shown that some isothiocyanates such as sulforaphane, allyl isothiocyanate and phenethyl isothiocyanate and their degradation products possess antineoplastic activities that are exerted through the induction of phase II enzymes, by the block of cell cycle and the induction of apoptosis or through the inhibition of tumor invasion and of angiogenesis (Meng \& al. 2000; Hecht 2000; Conaway \& al. 2002; Riedl \& al. 2009; Dinkova-Kostova \& al. 2012; Yang \& al. 2016).

The cardiovascular effects are certainly due to the antioxidant properties of polyphenols, carotenes and vitamins and to their ability to lower cholesterol levels in blood (Jones $\&$ al. 2000; Scialabba \& al. 2010). Instead, the anti-inflammatory properties are attributable to their capacity to decrease proinflammatory cytokines such as tumor necrosis factor$\alpha$ (TNF- $\alpha$ ), interleukin-6 (IL-6), and to increase the levels of anti-inflammatory cytokines such as IL-10 and IL-22 (Ferruzza \& al. 2016; Sotokawauchi \& al. 2018). Despite the large biological activities reported for several species and cultivars belonging to Brassicaceae, not many studies have been conducted on the wild Sicilian taxa object of the present review (Table 2). Faulkner and collaborators reported that extracts from inflorescences of B. drepanensis, B. villosa and hybrids between these two wild species and commercial broccoli cultivars, were potent inducers of quinone reductase activity in murine hepatoma cells (Faulkner \& al. 1998). The quinone reductase activity is strictly correlated with the induction of phase II detoxification enzymes such as glutathione transferase and UDP-glucuronosyl transferase. Extracts from the wild species and hybrids exhibited a strong significant increase in the ability to induce quinone reductase respect to the commercial cultivars, due to the greater glucosinolate content and the higher conversion to sulphoraphane (Faulkner \& al. 1998). After, other studies reported only results on the antioxidant capacity of different tissues extracts performed by various tests. However, all the samples examined showed a good antioxidant capacity, closely related to the phytochemical profile (Branca $\&$ al. 2013; Miceli \& al. 2020; Picchi \& al. 2020). Such experimental data based on so nonidentical conditions provide extremely different outcomes which result hardly to compare. 
In another research, since B. macrocarpa resulted to be the rich of glucosinolates compounds in the leaves, the biomass of this species was tested against the root-knot nematode attacks (Meloidogyne spp.) on tomato crops. The study showed that the addition of $B$. macrocarpa biomass to the substratum significantly reduced the diffusion of root knot nematodes indicanting the potential use of B. macrocarpa as a biofumigant for the control of this pest (Argento \& al. 2019).

Lastly in a recent study, two $B$. incana extracts from leaf and inflorescence were evaluated for their antitumor potential on MCF-7 and CaCo-2 cancer cell lines. Both extracts showed no appreciable cytotoxic activity on MCF-7 cell line conversely, both the extracts showed a dose dependent manner cytotoxic effect on CaCo-2 cells accompanied by a timeand dose-dependent release of lactate dehydrogenase, a well-known marker of necrotic cell death. The authors also reported that the extract from inflorescence, despite the lower phenolic content and radical scavenging activity, exerted a higher cytotoxic action than the extract from leaf in a cell model of colon cancer. Furthermore, both extracts from $B$. incana exhibited no toxicity in the brine shrimp lethality bioassay indicating their potential safety use (Miceli \& al. 2020).

Table 2. Biological activities of some wild Sicilian taxa of Brassica sect. Brassica.

\begin{tabular}{|c|c|c|c|}
\hline Taxa & Plant Organ & Biological test & References \\
\hline $\begin{array}{l}\text { B. drepanensis } \\
\text { B. villosa }\end{array}$ & Inflorescence & $\begin{array}{c}\text { Quinone Reductase } \\
\text { Activity }\end{array}$ & $\begin{array}{c}\text { Faulkner \& al. } \\
1998\end{array}$ \\
\hline $\begin{array}{l}\text { B. incana } \\
\text { B. rupestris } \\
\text { B. villosa } \\
\text { B. macrocarpa }\end{array}$ & Leaf & $\begin{array}{l}\text { DPPH Scavenging Activity } \\
\text { Crocin Bleaching }\end{array}$ & $\begin{array}{c}\text { Branca \& al. } \\
2013\end{array}$ \\
\hline B. macrocarpa & Leaf & $\begin{array}{l}\text { Root-Knot Nematodes } \\
\text { Meloidogyne spp }\end{array}$ & $\begin{array}{c}\text { Argento \& al. } \\
2019\end{array}$ \\
\hline B. incana & Leaf and Inflorescence & $\begin{array}{l}\text { Superoxide Anion Activity } \\
\text { DPPH Scavenging Activity } \\
\text { MTT Assay, LDH Release } \\
\text { Brine Shrimp Lethality Bioassay }\end{array}$ & $\begin{array}{l}\text { Miceli \& al. } \\
\quad 2020\end{array}$ \\
\hline B. incana & & & \\
\hline $\begin{array}{l}\text { B. macrocarpa } \\
\text { B. villosa } \\
\text { B. rupestris }\end{array}$ & Leaf & $\begin{array}{l}\text { Superoxide Anion Activity } \\
\text { DPPH Scavenging Activity }\end{array}$ & $\begin{array}{l}\text { Picchi \& al. } \\
\quad 2020\end{array}$ \\
\hline
\end{tabular}




\section{Discussion and conclusions}

Despite the few studies, the majority of the wild Sicilian taxa of Brassica sect. Brassica (Brassicaceae) examined in the last decades have been found to be a rich source of phytochemical compounds compared to the most cultivated variety belonging the $B$. oleracea group. Although, the partial data and the various outcomes reported by the different authors, on one hand confirms the potential of some taxa as a source of phytochemicals with a promising broad range of biological activities, on the other hand highlights the necessity to study and to better characterize the phytochemical profiles of each taxon with a systematic identification of the various classes of secondary metabolites present in some important plant organs such as leaf, inflorescence, root and seed, together with more indepth studies focused on their promising biological and pharmacological properties. These species and subspecies with their primary and unique gene pool may represent a very useful tool, not only for the genetic improvement of Brassica crops, but also for their possible cultivation and commercialization as superfood, since they are traditionally used as edible plants in Sicily, and in addition for the use in nutraceutical and pharmaceutical applications. The taxonomic updating carried out and the recognition of new subspecies that accentuate the character of the island of Sicily as a diversification center of the Brassica sect. Brassica, offers further research opportunities aimed also at the further enhancement of the interesting biological resource which is still little known.

\section{Acknowledgments}

We are grateful to Gianniantonio Domina for his critical reading of the text, to Enrico Bajona, promising student of the University of Palermo, for his support during the collections in the field of the plants studied.

\section{References}

Argento, S., Melilli, M. G. \& Branca, F. 2019: Enhancing Greenhouse Tomato-Crop Productivity by Using Brassica macrocarpa Guss. Leaves for Controlling Root-Knot Nematodes. - Agronomy 9(12): 820. https://doi.org/10.3390/agronomy9120820

Bartolucci, F., Peruzzi, L., Galasso, G., Albano, A., Alessandrini, A., Ardenghi, N. M. G., Astuti, G., Bacchetta, G., Ballelli, S., Banfi, E., Barberis, G., Bernardo, L., Bouvet, D., Bovio, M., Cecchi, L., Di Pietro, R., Domina, G., Fascetti, S., Fenu, G., Festi, F., Foggi, B., Gallo, L., Gottschlich, G., Gubellini, L., Iamonico, D., Iberite, M., Jiménez-Mejías, P., Lattanzi, E., Marchetti, D., Martinetto, E., Masin, R. R., Medagli, P., Passalacqua, N. G., Peccenini, S., Pennesi, R., Pierini, B., Poldini, L., Prosser, F., Raimondo, F. M., Roma-Marzio, F., Rosati, L., Santangelo, A., Scoppola, A., Scortegagna, S., Selvaggi, A., Selvi, F., Soldano, A., Stinca, A., Wagensommer, R. P., Wilhalm, T. \& Conti, F. 2018: An updated checklist of the vascular flora native to Italy. - Plant Biosystems 152(2): 179-303. https://doi.org/10.1080/11263504.2017.1419996

Baecher, C. W. W. 1994: Cancer preventive properties of Brassica oleracea: a review. - Amer. J. Clin. Nutr. 59(Suppl. 5): 1166-1170. https://doi.org/https://doi.org/10.1093/ajcn/59.5.1166S

Berni, R., Cantini, C., Romi, M., Hausman, J. F., Guerriero, G. \& Cai, G. 2018: Agrobiotechnology Goes Wild: Ancient Local Varieties as Sources of Bioactives. - Int. J. Molec. Sci. 19(8): 2248. https://doi.org/10.3390/ijms19082248 
Branca, F., Chiarenza, G. L., Cavallaro, C., Gu, H., Zhao, Z. \& Tribulato, A. 2018: Diversity of Sicilian broccoli (Brassica oleracea var. italica) and cauliflower (Brassica oleracea var. botrytis) landraces and their distinctive bio-morphological, antioxidant, and genetic traits. Gen. Res. Crop Evol. 65(2): 485-502. https://doi.org/10.1007/s10722-017-0547-8

—, Li, G., Goyal, S. \& Quiros, C. F. 2002: Survey of aliphatic glucosinolates in Sicilian wild and cultivated Brassicaceae. - Phytochemistry 59(7): 717-724. https://doi.org/10.1016/s00319422(02)00028-6

—, Ragusa, L., Tribulato, A., Bagatta, M., Lo Scalzo, R. \& Picchi, V. 2013: Evaluation of sicilian wild Brassica species $(n=9)$ for glucosinolate profile and antioxidant compounds. - Acta Hortic. 1005: 181-188. https://doi.org/10.17660/ActaHortic.2013.1005.18

Brullo, C., Brullo, S., Giusso del Galdo, G. \& Ilardi, V. 2013: Brassica trichocarpa (Brassicaceae), a new species from Sicily. - Phytotaxa 122(1): 45-60. https://doi.org/ 10.11646/phytotaxa.122.1.2

Conaway, C. C., Yang, Y. M. \& Chung, F. L. 2002: Isothiocyanates as cancer chemopreventive agents: their biological activities and metabolism in rodents and humans. - Curr Drug Metab. 3(3): 233-255. https://doi.org/10.2174/1389200023337496

Dinkova-Kostova, A. T. \& Kostov, R. V. 2012: Glucosinolates and isothiocyanates in health and disease. - Trends Mol Med. 18(6): 337-347. https://doi.org/10.1016/j.molmed.2012.04.003

Faulkner, K., Mithen, R. \& Williamson, G. 1998: Selective increase of the potential anticarcinogen 4-methylsulphinylbutyl glucosinolate in broccoli. - Carcinogenesis 19(4): 605-609. https://doi.org/10.1093/carcin/19.4.605

Ferruzza, S., Natella, F., Ranaldi, G., Murgia, C., Rossi, C., Trost, K., Mattivi, F., Nardini, M., Maldini, M., Giusti, A. M., Moneta, E., Scaccini, C., Sambuy, Y., Morelli, G. \& Baima, S. 2016: Nutraceutical improvement increases the protective activity of broccoli sprout juice in a human intestinal cell model of gut inflammation. - Pharmaceuticals 9(3): 48. https://doi.org/10.3390/ph9030048

Gan, R. Y., Lui, W. Y., Wu, K., Chan, C. L., Dai, S. H., Sui, Z. Q. \& Corke, H. 2017: Bioactive compounds and bioactivities of germinated edible seeds and sprouts: An updated review. - Trends Food Sci. Technol. 59: 1-14. https://doi.org/10.1016/j.tifs.2016.11.010

Geraci, A., Chevre, A., Divaret, I., Eber, F. \& Raimondo, F. M. 2004: Isozyme analysis of genetic diversity in wild Sicilian populations of Brassica sect. Brassica in view of genetic resources management. - Genetic Res. Crop Evol. 51: 137-146. https://doi.org/ 10.1023/B:GRES.00000208

Giamoustaris, A. \& Mithen, R. 1996: Genetics of aliphatic glucosinolates. IV. Side-chain modification in Brassica oleracea. - Theor. Appl. Genet. 93(5-6):1006-1010. https://doi.org/10.1007/BF00224105

Hecht, S. S. 2000: Inhibition of carcinogenesis by isothiocyanates. - Drug Metabolism Rev. 32(3-4): 395-411. https://doi.org/10.1081/dmr-100102342

Ilardi, V., Troía, A. \& Geraci, A. 2020: Brassica tardarae (Brassicaceae), a New Species from a Noteworthy Biotope of South-Western Sicily (Italy). - Plants 9(8): 947. https://doi.org/10.3390/plants9080947

Jones, P. J., Raeini-Sarjaz, M., Ntanios, F. Y., Vanstone, C. A., Feng, J. Y. \& Parsons, W. E. 2000: Modulation of plasma lipid levels and cholesterol kinetics by phytosterol versus phytostanol esters. - J. Lipid Res. 41(5): 697-705.

Kataya, H. A. \& Hamza, A. A. 2008: Red cabbage (Brassica oleracea) ameliorates diabetic nephropathy in rats. - Evid Based Complement Alternat Med. 5(3): 281-287. https://doi.org/10.1093/ecam/nem029

Le, T. N., Chiu, C. H. \& Hsieh, P. C. 2020: Bioactive compounds and bioactivities of Brassica oleracea L. var. italica sprouts and microgreens: an updated overview from a nutraceutical per- 
spective. - Plants 9(8): 946. https://doi.org/10.3390/plants9080946

Licata, M., Tuttolomondo, T., Leto, C., Virga, G., Bonsangue, G., Cammalleri, I., Gennaro, M. C., \& La Bella, S. 2016. A survey of wild plant species for food use in Sicily (Italy) - results of a 3year study in four Regional Parks. - J.Ethnobiol. Ethnomed. 12: 12.

Maggioni, L., von Bothmer, R., Poulsen, G., Branca, F. \& Bagger Jørgensen, R. 2014: Genetic diversity and population structure of leafy kale and Brassica rupestris Raf. in south Italy. Hereditas 151(6): 145-158. https://doi.org/10.1111/hrd2.00058

Miceli, N., Cavò, E., Ragusa, M., Cacciola, F., Mondello, L., Dugo, L., Acquaviva, R., Malfa, G. A., Marino, A., D'Arrigo, M. \& Taviano, M. F. 2020: Brassica incana Ten. (Brassicaceae): Phenolic Constituents, Antioxidant and Cytotoxic Properties of the Leaf and Flowering Top Extracts. - Molecules 25(6): 1461. https://doi.org/10.3390/molecules 25061461

Mithen, R. F., Lewis, B. G., Heaney, R .K. \& Fenwick, G. R. 1987: Glucosinolates of wild and cultivated Brassica species. - Phytochemistry 26(7): 1969-1973. https://doi.org/10.1016/S00319422(00)81740-9

Muscolo, A., Sidari, M., Settineri, G., Papalia, T., Mallamaci, C. \& Attinà, E. 2019: Influence of Soil Properties on Bioactive Compounds and Antioxidant Capacity of Brassica rupestris Raf. - J. Soil Sci. P1. Nutr. 19: 808-815. https://doi.org/10.1007/s42729-019-00080-5

Picchi, V., Lo Scalzo, R., Tava, A., Doria, F., Argento, S., Toscano, S., Treccarichi, S. \& Branca, F. 2020: Phytochemical Characterization and In Vitro Antioxidant Properties of Four Brassica Wild Species from Italy. - $\quad$ Molecules 25(15): 3495. https://doi.org/10.3390/molecules25153495

Prieto, M. A., López, C. J., \& Simal-Gandara, J. 2019: Glucosinolates: Molecular structure, breakdown, genetic, bioavailability, properties and healthy and adverse effects. - Advances Food Nutrition Res. 90: 305-350. https://doi.org/10.1016/bs.afnr.2019.02.008

Raimondo, F. M. 1997: Les membres italiens du complexe de Brassica oleracea: leur distribution et spécificités écologiques. - Bocconea 7: 103-106.

— \& Mazzola, P. 1997: A new taxonomic arrangement in the Sicilian member of Brassica L. sect Brassica. - Lagascalia 19: 831-838.

- _ — \& Ottonello, D. 1991: On the taxonomy and distribution of Brassica sect. Brassica (Cruciferae) in Sicily. - Fl. Medit. 1: 63-86.

-, Scialabba, A., Zecca, G., Grassi, F., Casazza, G., \& Minuto, L. 2012: Genetic variations in the endangered Sicilian endemic Brassica rupestris: proposals for a conservation strategy. - Pl. Biosyst. 146 (4): 847-857. https://doi.org/10.1080/11263504.2012.706237

— \& Spadaro, V. 2015: Diversity in the population of Brassica incana Ten. (Cruciferae) in Sicily. Biodiv. J. 6 (1): 193-196.

Riedl, M. A., Saxon, A. \& Diaz-Sanchez, D. 2009: Oral sulforaphane increases Phase II antioxidant enzymes in the human upper airway. - Clinical Immunol. 130(3): 244-251. https://doi.org/10.1016//j.clim.2008.10.007

Scialabba, A., Salvini, L., Faqi, A. S. \& Bellani L. M. 2010: Tocopherol, fatty acid and phytosterol content in seeds of nine wild taxa of Sicilian Brassica (Cruciferae). - Pl. Biosyst. 144(3): 626633. https://doi.org/10.1080/11263504.2010.490029

Sciandrello, S., Brullo, C., Brullo, S., Giusso del Galdo, G., Minissale, P. \& Salmeri C. 2013: A new species of Brassica sect. Brassica (Brassicaceae) from Sicily. - P1. Biosyst. 147(3): 812-820. https://doi.org/10.1080/11263504.2013.829885

Sotokawauchi, A., Ishibashi, Y., Matsui, T. \& Yamagishi, S. I. 2018: Aqueous extract of glucoraphanin-rich broccoli sprouts inhibits formation of advanced glycation end products and attenuates inflammatory reactions in endothelial cells. - Evidence-Based Complementary Alternative Med. 2018(1): 1-6. https://doi.org/10.1155/2018/9823141 
Tripodi, G., Verzera, A., Dima, G., Condurso, C. \& Ragusa, S. 2012: Brassica fruticulosa Cyr. and Brassica incana Ten. (Brassicaceae) as Mediterranean traditional wild vegetables: a valuable source of bioactive compounds. - J. Essential Oil Res. 24(6): 539-545. https://doi.org/10.1080/10412905.2012.730492

Yang, M., Wang, H., Zhou, M., Liu, W., Kuang, P., Liang, H. \& Yuan, Q. 2016: The natural compound sulforaphene, as a novel anticancer reagent, targeting PI3K-AKT signaling pathway in lung cancer. - Oncotarget 7(47): 76656-76666. https://doi.org/10.18632/oncotarget.12307

Addresses of the authors:

Giuseppe A. Malfa ${ }^{1}$, Rosaria Acquaviva ${ }^{1}$, Anahì A.E. Bucchini ${ }^{2}$, Salvatore Ragusa ${ }^{3}$, Francesco M. Raimondo 4 \& Vivienne Spadaro 5 ,

${ }^{1}$ Department of Drug Science, Biochemistry Section, University of Catania, 95123, Catania, Italy. E-mail: g.malfa@unict.it

${ }^{2}$ Department of Earth, Life and Environmental Sciences, University of Urbino, Orto Botanico, Via Bramante 28, 61029, Urbino, Italy.

${ }^{3}$ Department of Health Sciences, University Magna Graecia of Catanzaro, 88100, Catanzaro, Italy.

${ }^{4}$ PLANTA/Research, Documentation and Training Center, Via Serraglio Vecchio 28, 90123, Palermo, Italy.

${ }^{5}$ Department STEBICEF/Section of Botany, Anthropology and Zoology, University of Palermo, Via Archirafi 38, 90123, Palermo, Italy.

Corresponding author: Giuseppe A. Malfa 